\title{
Penerapan heutagogi gamifikasi terhadap evaluasi pembelajaran geografi di sekolah menengah pertama
}

\author{
Ahmad Mursyidun Nidhom ${ }^{1}$, Setiadi Cahyono Putro ${ }^{2}$ \\ 1. Universitas Negeri Malang, Indonesia | nidhom.ft@um.ac.id \\ 2. Universitas Negeri Malang, Indonesia | setiadi.cahyono.ft@um.ac.id
}

\begin{abstract}
Abstrak
Evaluasi pembelajaran dalam bentuk tes sering menimbulkan kecemasan pada diri siswa sehingga mempengaruhi hasil belajar terutama pada pelajaran yang membutuhkan konsentrasi dan daya ingat seperti pelajaran Geografi. Untuk menciptakan suasana evaluasi belajar yang santai dan tidak membuat siswa merasa cemas, dapat dilakukan dengan memanfaatkan game edukasi sebagai alat evaluasi pembelajaran. Game didesain dan dibangun seatraktif mungkin untuk siswa kelas IX SMP dengan aplikasi Java 3D dengan. Game edukasi yang user-friendly, mudah diaplikasikan dan atraktif membuat siswa tidak sadar bahwa sebenarnya ia sedang dievaluasi. Pemanfaatan game edukasi sebagai alternatif media evaluasi pembelajaran mampu mengurangi kecemasan siswa dan membuat hasil evaluasi belajar lebih mendekati kemampuan siswa yang sebenarnya. Dari Hasil Uji Coba Fleksibilitas dan user friendly dengan mekanisme black box mendapatkan nilai $87,3 \%$, hal ini menandakan konsep gamifikasi berjalan secara maksimal.
\end{abstract}

Kata Kunci

Heutagogi, gamifikasi, evaluasi pembelajaran, pendidikan

TEKNO Vol. 29 Issue 2, p190-197 | Jurusan Teknik Elektro, Universitas Negeri Malang, Indonesia | September 2019

A. M. Nidhom, S. C. Putro | Penerapan heutagogi gamifikasi terhadap evaluasi pembelajaran geografi di ... 


\section{TEKNO Jumal Teknologi, Elektro, dan Kkijuran}

http://journal2.um.ac.id/index.php/tekno | ISSN 1693-8739 / 2686-4657

\section{Pendahuluan}

Dalam pelaksanaan pembelajaran, sebuah evaluasi wajib dilaksanakan untuk mengetahui sejauh mana tujuan pembelajaran dicapai oleh siswa, baik dari segi efektivitas maupun efisiensinya (Mustaqim, 2017). Namun terkadang hasil evaluasi pembelajaran yang dilakukan tidak mencerminkan pencapaian hasil belajar siswa yang sebenarnya. Ada banyak hal yang menyebabkan hasil evaluasi belajar tidak sesuai dengan kemampuan siswa yang sesungguhnya, yaitu faktor luar dan faktor dalam (Hapnita dkk, 2018). Faktor luar contohnya adalah sarana dan prasarana pembelajaran (Setiawati dan Sudira, 2015), keadaan lingkungan belajar (Hapnita dkk, 2018), dan lain-lain. Sementara itu faktor dari dalam berarti faktor yang berasal dari siswa itu sendiri seperti misalnya kondisi fisik (Raresik dkk, 2016), kondisi psikologis (Iskandar dkk, 2016), maupun nasib siswa itu sendiri. Kondisi psikologis yang dapat memberi pengaruh negatif pada hasil evaluasi belajar siswa antara lain adalah kecemasan (Widodo dkk, 2017). Evaluasi pembelajaran yang lazimnya diwujudkan dalam bentuk tes sering menimbulkan kecemasan yang mengganggu fokus pada diri siswa, sehingga mempengaruhi hasil belajar terutama pada pelajaran yang membutuhkan konsentrasi dan daya ingat seperti pelajaran Geografi.

Sebuah penelitian mengungkapkan adanya hubungan antara kecemasan dengan hasil evaluasi belajar siswa (Suratmi dkk, 2017), yaitu besar kecilnya kecemasan mempengaruhi murni dan tidaknya hasil belajar, murid yang kurang pandai mempunyai kecemasan yang lebih besar dibandingkan dengan anak yang berkemampuan tinggi, kebiasaan terhadap tipe tes dan pengadministrasiannya mengurangi kecemasan dalam tes, dan dalam kecemasan yang tinggi, beberapa murid akan mencapai hasil yang baik bila jawaban soal menyangkut ingatan tapi hasilnya akan tidak baik jika jawaban soal berupa pemikiran.

Mengingat bahwa hasil evaluasi pembelajaran digunakan untuk menentukan tingkat pencapaian siswa bahkan kelulusan siswa pada suatu pembelajaran (Mahirah, 2017), maka sangat penting untuk memperoleh hasil yang sesuai kenyataan. Oleh karena itu, evaluator harus mengupayakan alternatif cara melakukan evaluasi belajar yang santai namun tetap tidak kehilangan fungsinya sebagai alat untuk mengukur kemampuan seseorang.

Salah satu cara yang dapat diterapkan adalah dengan pemanfaatan game sebagai instrumen evaluasi pembelajaran (Sasongko, 2017). Mata pelajaran yang dipilih sebagai sampel adalah Geografi kelas IX SMP.Game untuk media evaluasi pelajaran tersebut didesain seatraktif mungkin dengan bahasa pemrograman seperti misal Java 3D dan menarik perhatian sehingga siswa senang memainkannya. Skor yang dihasilkan dari game ini digunakan sebagai ganti nilai tes yang selanjutnya dapat digunakan untuk menganalisa hasil belajar siswa. Dengan memanfaatkan game ini, siswa tidak akan merasa bahwa dirinya sedang dievaluasi sehingga siswa dapat lebih santai dalam menjawab soal yang diajukan. Jawaban yang diberikan pun cenderung sesuai dengan kemampuannya yang sebenarnya.

TEKNO Vol. 29 Issue 2, p190-197 | Jurusan Teknik Elektro, Universitas Negeri Malang, Indonesia | September 2019

A. M. Nidhom, S. C. Putro | Penerapan heutagogi gamifikasi terhadap evaluasi pembelajaran geografi di ... 


\section{TEKNO Jumal Teknologi, Elektro, dan Kejuruon}

http://journal2.um.ac.id/index.php/tekno | ISSN 1693-8739 / 2686-4657

Yang menjadi masalah adalah bagaimana pemanfaatan game edukasi dalam evaluasi pembelajaran serta bagaimana pengaruhnya terhadap hasil evaluasi pembelajaran tersebut. Selama ini masih jarang penelitian seputar pemanfaatan game edukasi dalam evaluasi pembelajaran sehingga paper ini bertujuan untuk meneliti pemanfaatan game edukasi sebagai media evaluasi belajar serta pengaruhnya terhadap kemurnian hasil belajar.

\section{Metode}

\section{A. Rancangan Penelitian}

Game edukasi yang dibuat untuk diimplementasikan sebagai alternatif instrumen evaluasi pembelajaran pada mata pelajaran Geografi adalah game penjelajahan dengan memanfaatkan peta buta. Game ini dibuat dengan tujuan agar siswa mampu mengidentifikasi ciri-ciri maupun bentang alam khusus yang dimilki suatu daerah pada suatu benua. Materi mengenai ciri khas flora dan fauna serta bentang alam benua yang ada di bumi ini terdapat pada mata pelajaran Geografi kelas IX SMP. Adapun gambaran umum dari game edukasi ini adalah sebagai berikut : 1) Game ini pada dasarnya merupakan pengembangan dari peta buta konvensional yang kemudian dikembangkan bentuk digitalnya; 2) Alokasi waktu yang disediakan untuk menyelesaikan game ini secara keseluruhan adalah 60 menit; 3) Total seluruh spot pertanyaan pada game ini adalah 25 buah; 4) Sebelum mulai bermain, pemain harus mengisikan identitasnya yaitu nama dan nomor absen; 5) Halaman utama akan menampilkan bentuk muka bumi dan benua-benua yang ada;6) Pemain memilih di benua mana ia akan bermain terlebih dahulu dengan meng-klik radio button yang ada pada tiap-tiap benua; 6) Game akan menampilkan peta buta dari benua yang telah dipilih dengan ukuran besar. Pada peta tersebut akan terdapat beberapa spot merupakan bentang alam, barang tambang maupun habitat fauna khas benua tersebut; 7) Pemain harus meng-klik spot tersebut untuk menampilkan pertanyaan pada spot tersebut dan menjawabnya; 8) Tiap jawaban yang diberikan akan langsung diberi skor. Jawaban yang benar diberi nilai 4 dan jawaban salah bernilai 0 ; 9) Setelah menjawab pertanyaan pada spot tersebut, pemain tidak bisa mengulangi jawabannya dan harus melanjutkan ke spot berikutnya;10) Bila pertanyaan dari seluruh spot di suatu benua telah dijawab maka pemain kembali ke menu utama dan memilih benua yang lain untuk dijelajahi. Benua yang telah dipilih sebelumnya di set dalam keadaan unable sehingga tidak bisa dipilih kembali; 11) Bila seluruh benua telah dijelajahi maka software game edukasi tersebut akan menjumlahkan total skor yang dimiliki pemain dan menampilkannya di halaman utama; 12) Skor total yang berhasil dikumpulkan pemain selanjutnya dikelompokkan ke dalam kategori yang telah ditentukan sebelumnya dan dianalisa apakah siswa tersebut mampu mencapai kompetensi yang diharapkan atau tidak.

Pada makalah ini pengujian dilakukan dengan menggunakan metode black-box yang akan akan menguji hasil keluaran dari produk aplikasi game edukasi berdasarkan masukkan yang diberikan. Prosedur pengujian adalah dengan mengujiakan fungsi-fungsi utama yang diosajikan

TEKNO Vol. 29 Issue 2, p190-197 | Jurusan Teknik Elektro, Universitas Negeri Malang, Indonesia | September 2019

A. M. Nidhom, S. C. Putro | Penerapan heutagogi gamifikasi terhadap evaluasi pembelajaran geografi di ... 


\section{TEKNO Jumal Teknologi, Elekro, dan Kejuruan}

http://journal2.um.ac.id/index.php/tekno | ISSN 1693-8739 / 2686-4657

dalam game edukasi ini. Fungsi-funsi utama yang dimaksud disini sesuai dengan perancangan proses yang didefinisikan pada tahap analisis. Pada tahap pengujian perancangan proses belum ditemukan kesalahan atau keluaran yang sesuai dengan scenario yang telah didefinisikan sebelumnya. Setelah user berhasil menjawab seluruh pertanyaan nilai yang tampil pada menu utama sesuai dengan jumlah jawaban benar yang diisikan oleh user. Dan nilai total skor hanya akan tampil seluruh pertanyaan telah dijawab, hal tersebut sudah dengan dekripsi yang pada fitur game yang dideskripsikan pada tahap analisis.

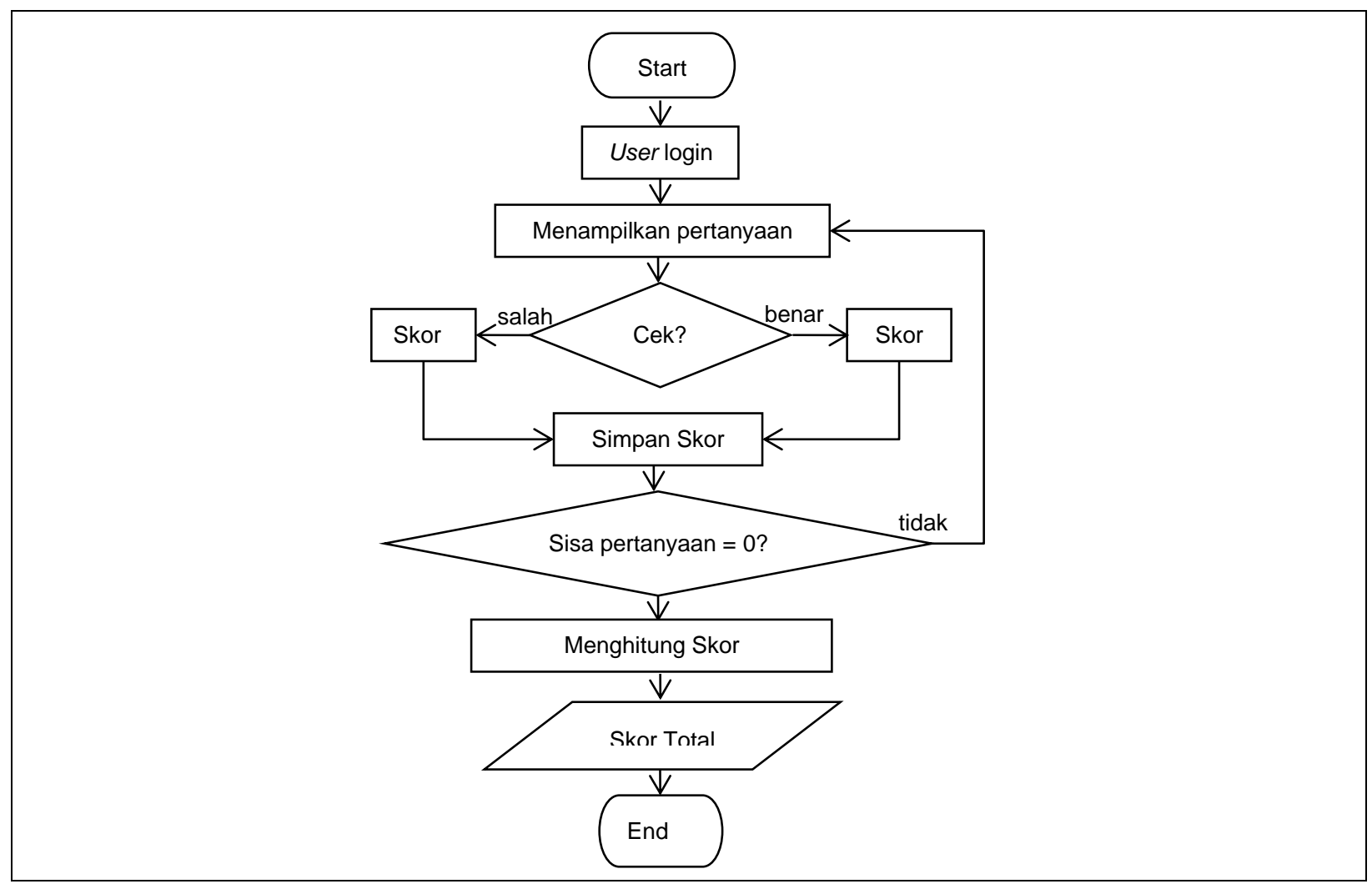

Gambar 1. Diagram Alur Gamifikasi

\section{B. Implementasi dan Pengujian}

Game edukasi ini terdiri dari satu form utama, 5 form sekunder yang masing-masing mewakili 5 benua yang akan dijelajahi dan masing-masing 5 form untuk tiap benua. 5 form tersebut berisi pertanyaan yang harus dijawab user.

Rancangan Antarmukanya merupakan form yang pertama kali muncul saat game dijalankan. Pada form ini terdapat menu file dan help serta 1 button untuk memulai permaianan. Antarmuka form utama ditunjukkan oleh Gambar 2. 


\section{TEKNO Jumal Teknologi, Elektro, dan Kejivruan}

http://journal2.um.ac.id/index.php/tekno | ISSN 1693-8739 / 2686-4657
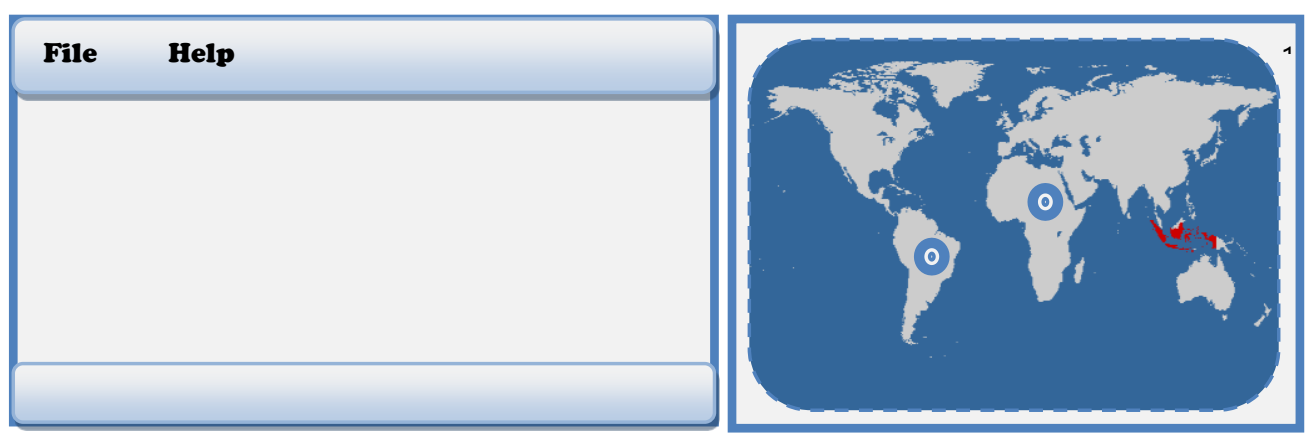

Gambar 2. Form Antar Muka Aplikasi

\section{Arsitektur Sistem}

Arsitektur dari program game edukasi ini terdiri dari dua subsistem program yaitu subsistem antarmuka dan sub sistem untuk penilaian (skoring). llustrasi mengenai arsitektur program ini ditunjukkan oleh Gambar 3.

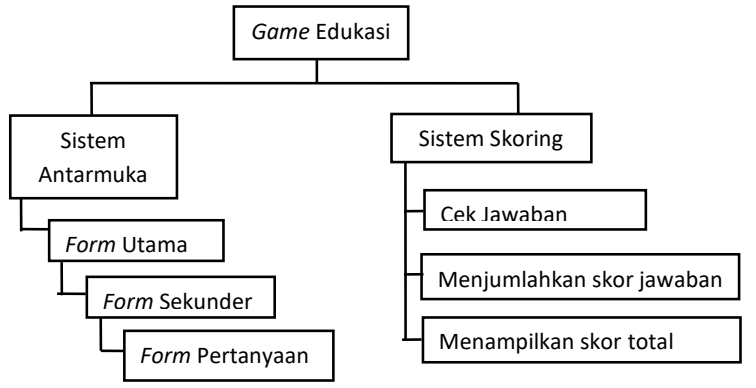

Gambar 3. Arsitektur Program

Setiap software pasti terdiri dari beberapa proses di dalamnya. Proses yang ada dalam program game edukasi ini digambarkan dalam bentuk DFD (Data Flow Diagram) dan ditunjukkan oleh Gambar 4. Pada perancangan proses program yang terlihat pada Gambar 4 merupakan bentuk DFD (Data Flow Diagram) level 0 dimana digambarkan bahwa sistem game edukasi ini dapat digunakan oleh user dengan menekan tombol mulai yang merupakan instruksi untuk membuka form berikutnya. Kemudian user memainkan game tersebut dan mengisi jawaban dari setiap pertanyaan yang diajukan hingga akhirnya seluruh pertanyaan habis terjawab dan user 


\section{TEKNO Jumal Teknologi, Eektro, dan Kejivuan}

http://journal2.um.ac.id/index.php/tekno | ISSN 1693-8739 / 2686-4657

menekan tombol skor pada menu utama dan game akan menampilkan total nilai dari jawaban yang telah dijawab oleh user sebelumnya.

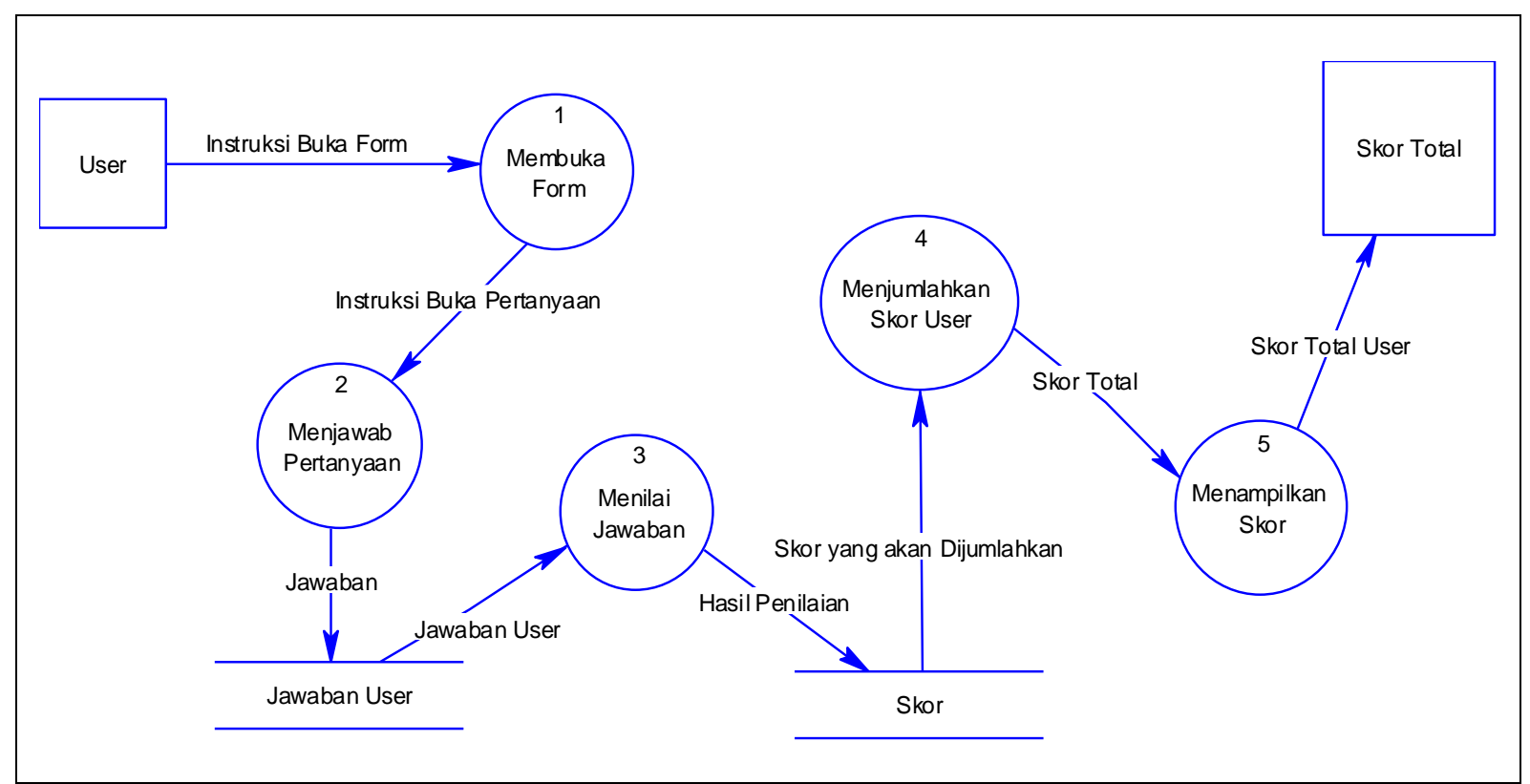

Gambar 4. DFD Diagram

Selanjutnya, game diuji coba pada sebanyak 30 siswa kelas IX. Uji coba dilakukan dengan dengan mekanisme pengujian black box. Dari Hasil Uji Coba Fleksibilitas dan user friendly mendapatkan nilai $87,3 \%$ seperti yang ditunjukkan pada Tabel 1 . Hal ini menandakan konsep gamifikasi berjalan secara maksimal. Pemanfaatan game edukasi sebagai alternatif media evaluasi pembelajaran mampu mengurangi kecemasan siswa. Selain itu, pemanfaatan game edukasi juga berdampak pada hasil evaluasi belajar lebih mendekati kemampuan siswa yang sebenarnya (Wulandari dkk, 2017).

Tabel 1. Hasil uji coba produk penelitian

\begin{tabular}{lllc}
\hline No. & Sub Variabel & Jumlah & Persentase Rata-rata \\
\hline 1. & Efektifitas & 5 variabel & $23 \%$ \\
2. & Efisiensi & 5 variabel & $30 \%$ \\
3. & Uji Usability & $\mathbf{7}$ variabel & $34,3 \%$ \\
\hline & Total & $\mathbf{1 7}$ variabel & $\mathbf{8 7 , 3} \%$ \\
\hline
\end{tabular}




\section{TEKNO Jumal Teknologi, Ekekro, dan Kejuruon}

http://journal2.um.ac.id/index.php/tekno | ISSN 1693-8739 / 2686-4657

\section{Kesimpulan dan Saran}

\section{Kesimpulan}

Bedasarkan hasil penelitian yang telah dilakukan, dapat diperoleh kesimpulan yakni Perangkat lunak game edukasi geografi ini dibangun dengan menggunakan bahasa pemrograman Java 3D. Tiap pertanyaan pada game ini merepresentasikan bentang alam yang ada di tiap benua di seluruh dunia. Skor yang diperoleh dari permainan ini dapat membantu guru dalam melakukan penilaian terhadap kompetensi siswa. Selain itu game edukasi untuk pelajaran Geografi ini adalah game edukasi yang user-friendly, mudah diaplikasikan dan atraktif sehingga membuat siswa tidak sadar bahwa sebenarnya ia sedang dievaluasi. Pemanfaatan game edukasi sebagai alternatif media evaluasi pembelajaran mampu mengurangi kecemasan siswa dan membuat hasil evaluasi belajar lebih mendekati kemampuan siswa yang sebenarnya.

\section{Saran}

Game edukasi ini dapat digunakan sebagai salah satu bentuk lain dari evaluasi pembelajaran terutama untuk pelajaran Geografi kelas IX. Game ini sangat berguna bagi guru maupun bagi siswa, karena siswa tidak lagi merasa takut, tegang, dan cemas dalam menghadapi ujian atau evaluasi. Di lain pihak, guru dapat dengan memperoleh hasil evaluasi dengan mudah (melalui skor) serta sesuai dengan kemampuan asli siswa. Guru juga dapat menggunakan game ini sebagai alat untuk mengukur apakah siswa sudah paham dengan materi yang disampaikan atau belum dengan cara memberikan game ini terlebih dahulu sebelum melakukan evaluasi yang sesungguhnya. Dari skor yang diperoleh, guru akan memperoleh gambaran apakah siswa sudah menguasai materi atau belum serta materi yang ada pada benua mana yang kurang dikuasai siswa sehingga guru dapat melakukan pendalaman ataupun pengayaan. Game edukasi ini dapat menjadi salah satu inovasi dalam hal evaluasi pembelajaran berbasis game dan dapat menjadi inspirasi bagi yang lain untuk dapat terus mengembangkan pengetahuannya khususnya dalam bidang pendidikan atau edukasi.

\section{Daftar Rujukan}

Hapnita, W., Abdullah, R., Gusmareta, Y., dan Rizal, F. 2018. Faktor Internal dan Eksternal yang Dominan Mempengaruhi Hasil Belajar Menggambar dengan Perangkat Lunak Siswa Kelas XI Teknik Gambar Bangun SMKN 1 Padang Tahun 2016/2017. Cived Jurusan Teknik Sipil, $5,1,2175-2182$.

Iskandar, N., Setiawan, A., dan Sumardi, K. 2016. Identifikasi Faktor-Faktor yang Mempengaruhi Siswa SMK Memilih Program Keahlian Teknik Mesin. Journal of Mechanical Engineering Education, 3, 2, 220-224.

Mahirah, B. 2017. Evaluasi Belajar Peserta Didik (Siswa). Jurnal Idaarah, 1, 2, 257-267.

TEKNO Vol. 29 Issue 2, p190-197 | Jurusan Teknik Elektro, Universitas Negeri Malang, Indonesia | September 2019

A. M. Nidhom, S. C. Putro | Penerapan heutagogi gamifikasi terhadap evaluasi pembelajaran geografi di ... 


\section{TEKNO Junnal Teknologi, Elekkro, dan Kejuruan}

http://journal2.um.ac.id/index.php/tekno | ISSN 1693-8739 / 2686-4657

Mustaqim, M. 2017. Model Evaluasi Pembelajaran STAIN Kudus (Studi Kasus Sitem Evaluasi Pembelajaran Dosen Prodi Manajemen Bisnis Syari'ah STAIN Kudus). Quality, 5, 1, 155-169.

Raresik, Kd. A., Dibia, I Kt., dan Widiana, I Wyn. 2016. Analisis Faktor-Faktor yang Mempengaruhi Hasil Belajar Bahasa Indonesia pada Siswa Kelas V SD Gugus VI .e-Journal PGSD Universitas Pendidikan Ganesha, 4, 1, 1-11.

Sasongko, G. W. dan Suswanto, H. 2017. Pengembangan Game sebagai Media Evaluasi Pembelajaran pada Mata Pelajaran Perakitan Komputer Kelas X Jurusan Multimedia. Jurnal Pendidikan: Teori, Penelitian, dan Pengembangan, 2, 7, 1017-1023.

Setiawati, L. dan Sudira, P. 2015. Faktor-Faktor yang Mempengaruhi Prestasi Belajar Praktik Kejuruan Siswa SMK Program Studi Keahlian Teknik Komputer dan Informatika. Jurnal Pendidikan Vokasi, 5, 3, 325-339.

Suratmi, Abdullah, R., dan Taufik, M. 2017. Hubungan antara Tingkat Kecemasan dengan Hasil Belajar Mahasiswa di Program Studi Pendidikan Biologi Untirta. Jurnal Pembelajaran Biologi, 4, 1, 71-76.

Widodo, S. A., Laelasari, Sari, R. M., Nur, I. R. D., dan Putrianti, F. G. 2017. Analisis Faktor Tingkat Kecemasan, Motivasi dan Prestasi Belajar Mahasiswa. Jurnal Taman Cendekia, 1, 1, 67-77.

Wulandari, R., Susilo, H., dan Kuswandi, D. 2017. Penggunaan Multimedia Interaktif Bermuatan Game Edukasi untuk Meningkatkan Aktivitas dan Hasil Belajar Siswa Sekolah Dasar. Jurnal Pendidikan: Teori, Penelitian, dan Pengembangan, 2, 8, 1024-1029. 